\title{
Ferrocyanide Safety Program: Thermal Analysis of Ferrocyanide Watch List Tanks, Group II
}

\author{
J. M. McLaren
}

Date Published

September 1994

Prepared for the U.S. Department of Energy Office of Environmental Restoration and Waste Management

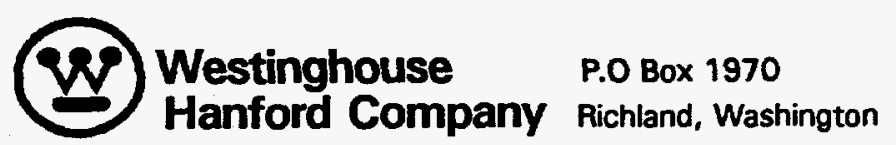

Hanford Operations and Engineering Contractor for the

U.S. Department of Energy under Contract DE-AC06-87RL10930 


\section{RELEASE AUTHORIZATION}

\section{Document Number: WHC-EP-0794}

Document Title: $\quad$ Ferrocyanide Safety Program: Thermal Analysis of Ferrocyanide Watch List Tanks, Group II

Release Date: $\quad$ September 23, 1994

This document was reviewed following the procedures described in WHC-CM-3-4 and is:

APPROVED FOR PUBLIC RELEASE

WHC Information Release Administration Specialist:

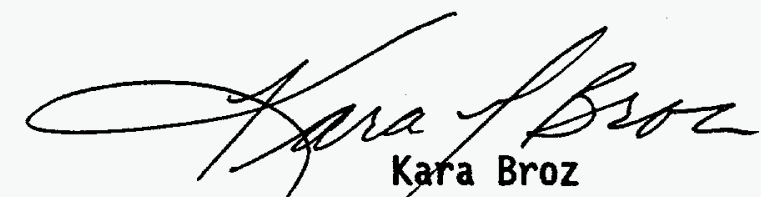

(Signature)
September 23, 1994

(Date) 


\section{DISCLAIMER}

This report was prepared as an account of work sponsored by an agency of the United States Government. Neither the United States Government nor any agency thereof, nor any of their employees, make any warranty, express or implied, or assumes any legal liability or responsibility for the accuracy, completeness, or usefulness of any information, apparatus, product, or process disclosed, or represents that its use would not infringe privately owned rights. Reference herein to any specific commercial product, process, or service by trade name, trademark, manufacturer, or otherwise does not necessarily constitute or imply its endorsement, recommendation, or favoring by the United States Government or any agency thereof. The views and opinions of authors expressed herein do not necessarily state or reflect those of the United States Government or any agency thereof. 


\section{DISCLAIMER}

Portions of this document may be illegible in electronic image products. Images are produced from the best available original document. 


\section{CONTENTS}

1.0 INTRODUCTION $\ldots \ldots \ldots \ldots \ldots \ldots \ldots \ldots \ldots \ldots \ldots \ldots \ldots$ 1-1

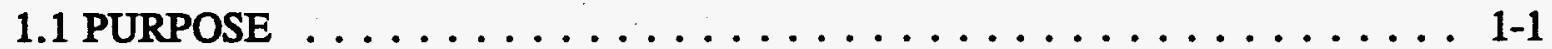

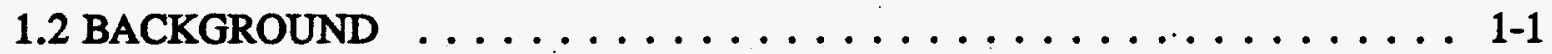

2.0 SUMMARY OF RESULTS $\ldots \ldots \ldots \ldots \ldots \ldots \ldots \ldots \ldots \ldots \ldots \ldots \ldots \ldots \ldots$

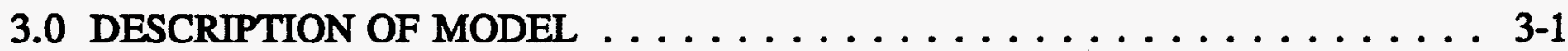

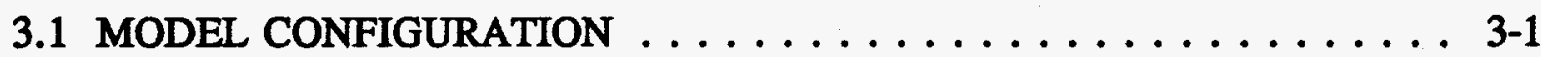

3.2 HEAT TRANSFER MODELING $\ldots \ldots \ldots \ldots \ldots \ldots \ldots \ldots \ldots$. $\ldots \ldots$

3.3 SOIL CONDUCTIVITY $\ldots \ldots \ldots \ldots \ldots \ldots \ldots \ldots \ldots \ldots \ldots$

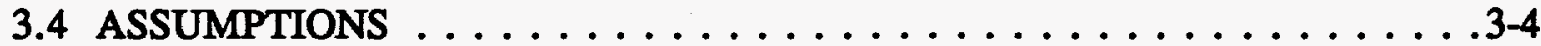

3.4.1 Atmosphere . . . . . . . . . . . . . . . . .

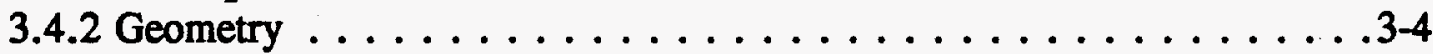

3.5 INPUT DATA AND UNCERTAINTIES $\ldots \ldots \ldots \ldots \ldots \ldots \ldots . \ldots . \ldots$

3.6 HEAT LOAD DETERMINATION METHOD $\ldots \ldots \ldots \ldots \ldots \ldots \ldots$ 3-5

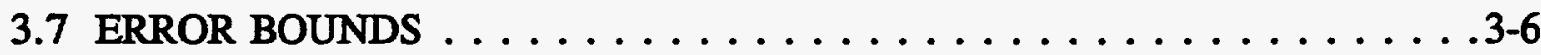

4.0 RESULTS $\ldots \ldots \ldots \ldots \ldots \ldots \ldots \ldots \ldots \ldots \ldots \ldots \ldots \ldots \ldots \ldots . \ldots \ldots \ldots$

4.1 GROUP A . . . . . . . . . . . . . .

4.1.1 Analysis of Tank $241-C-111 \ldots \ldots \ldots \ldots \ldots \ldots \ldots \ldots$ 4-2

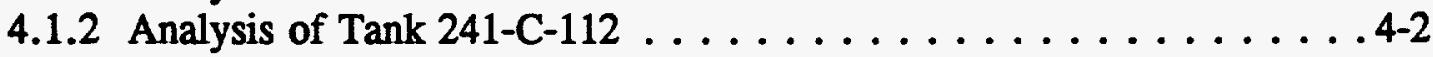

4.2 GROUP B . . . . . . . . . . . . . . . . 4 4

4.2.1 Analysis of Tank $241-\mathrm{TY}-103 \ldots \ldots \ldots \ldots \ldots \ldots \ldots \ldots$. . . . . . .

4.2.2 Analysis of Tank $241-\mathrm{TY}-104 \ldots \ldots \ldots \ldots \ldots \ldots \ldots \ldots$. . . . . . . .

4.3 GROUP C . . . . . . . . . . . . . . . . 4-7

4.3.1 Analysis of Tank $241-\mathrm{BY}-112 \ldots \ldots \ldots \ldots \ldots \ldots \ldots \ldots$. .8

4.3.2 Analysis of Tank $241-\mathrm{TX}-118 \ldots \ldots \ldots \ldots \ldots \ldots \ldots$. . . . . . . . . .

5.0 COMPILATION OF RESULTS $\ldots \ldots \ldots \ldots \ldots \ldots \ldots \ldots \ldots \ldots \ldots$

6.0 REFERENCES . . . . . . . . . . . . . .

APPENDIX

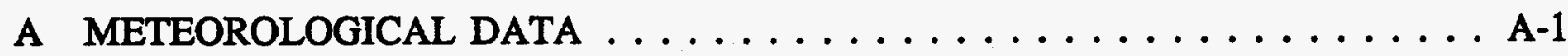




\section{LIST OF FIGURES}

3-1. Typical HEATING7 Model of 2,839,000-Liter (750,000-Gallon)

Waste Storage Tank . . . . . . . . . . . . . . . . . . . . .3-2

4-1. Tank 241-C-111 Fill/Transfer History $\ldots \ldots \ldots \ldots \ldots \ldots \ldots \ldots \ldots$. . . . . . .

4-2. Tank 241-C-112 Fill/Transfer History $\ldots \ldots \ldots \ldots \ldots \ldots \ldots \ldots$. . . . . . .

4-3. Tank 241-C-112 Maximum Temperature Data History . . . . . . . . . . . 4-4

4-4. Tank 241-TY-103 Fill/Transfer History $\ldots \ldots \ldots \ldots \ldots \ldots$. . . . . . 4-5

4-5. Tank 241-TY-104 Fill/Transfer History $\ldots \ldots \ldots \ldots \ldots \ldots \ldots$. . . . . . .

4-6. Tank 241-TY-104 Estimated Temperature History . . . . . . . . . . . . 4-7

4-7. Tank 241-BY-112 Fill/Transfer History $\ldots \ldots \ldots \ldots \ldots \ldots$. . . . . . 4-8

4-8. Tank 241-BY-112 Assumed Maximum Temperature History $\ldots \ldots \ldots$. . . . 4-9

4-9. Tank 241-TX-118 Fill/Transfer History $\ldots \ldots \ldots \ldots \ldots \ldots$. . . . . . 4-10

\section{LIST OF TABLES}

2-1. Estimated Tank Heat Loads $\ldots \ldots \ldots \ldots \ldots \ldots \ldots$. . . . . . . . . .

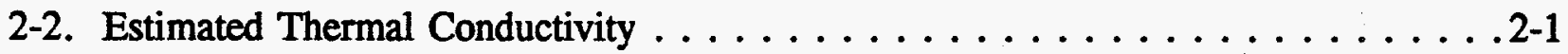

3-1. Nominal Soil Conductivity Values $\left(\mathrm{W} / \mathrm{m}-{ }^{\circ} \mathrm{C}\right) \ldots \ldots \ldots \ldots \ldots$. . . . . . .

3-2. Upper Bound Soil Conductivity Values $\left(\mathrm{W} / \mathrm{m}-{ }^{\circ} \mathrm{C}\right) \ldots \ldots \ldots \ldots \ldots$

3-3. Lower Bound Soil Conductivity Values $\left(\mathrm{W} / \mathrm{m}-{ }^{\circ} \mathrm{C}\right) \ldots \ldots \ldots \ldots$. . . . . . . .

4-1. Studied Tanks Grouped by Waste Level and Temperature . . . . . . . . . . 4-1

4-2. Results of Group A Analyses . . . . . . . . . . . . 4-2

4-3. Result of Group B Analyses $\ldots \ldots \ldots \ldots \ldots \ldots \ldots \ldots \ldots$. . . . . . .

4-4. Results of Group C Analyses . . . . . . . . . . . . . . 4-7

5-1. Summary of Heat Load Analyses $\ldots \ldots \ldots \ldots \ldots \ldots \ldots \ldots$. . . . . . . 


\section{FERROCYANIDE SAFETY PROGRAM: THERMAL ANALYSIS OF FERROCYANIDE WATCH LIST TANKS, GROUP II}

\subsection{INTRODUCTION}

\subsection{PURPOSE}

The purpose of this report is to document the results of a series of analyses conducted to determine the heat loads of the second of two groups of tanks on the Ferrocyanide Watch List. Tanks placed on the Ferrocyanide Watch List were divided into two groups. The results of the thermal analysis of the first group were reported in WHC-EP-0729, Ferrocyanide Safety Program: Thermal Analysis of Ferrocyanide Tanks, Group I (McLaren 1994) and in WHC-EP-0669, Ferrocyanide Safety Program: Updated Thermal Analysis Model for Ferrocyanide Tanks with Application to Tank 241-BY-104 (McLaren 1993).

The analyses of the second group of tanks used the fill/transfer history and tank temperature data with a transient solution for the heat load determination. Nominal heat load values were determined, as well as the upper and lower bounds of the heat load. Because the waste level in most of these tanks was low, thermal conductivity estimations could only be made for two tanks.

\subsection{BACKGROUND}

During the 1950 s, a program was begun to concentrate the radioactive waste products of the uranium and plutonium recovery processes. This program used sodium ferrocyanide and nickel sulfate to precipitate radioactive cesium from the waste streams (Borsheim and Simpson 1991). The precipitate, sodium and cesium nickel ferrocyanide, was then stored in large underground single-shell tanks at the Hanford Site in south central Washington State.

The precipitated solids also contain nitrates and nitrites. In 1989, a tank safety concern arose because ferrocyanide and nitrates/nitrites can be made to react violently if dried and raised to high temperatures $\left(>220^{\circ} \mathrm{C}\right)$.

Severat of the tanks have been "stabilized," a process that included removing as much pumpable liquid as possible from the tanks. This liquid contained heat-producing radionuclides. Because of the many transfers involved, the lack of accurate inventory data for the various waste streams, and the absence of a need for an accurate heat load value, the heat loads of the ferrocyanide tanks have only been estimated. 
As a result of the intense radiation field within these tanks, the chemical content of the waste has changed. This, coupled with the fact that the characteristics of the input waste were not well known, has resulted in unknown thermal characteristics of the stored sludge. All of the above parameters are needed to evaluate the safety of these tanks.

The method used in this report uses computer analysis of the tank and its contents, along with the temperature data obtained from in situ thermocouple trees, to determine the heat load of the tanks and the thermal conductivity of the waste. A computer model of the tank and its contents is used that also includes the surrounding soil, which is the main heat sink. 


\subsection{SUMMARY OF RESULTS}

The second group of Ferrocyanide Watch List tanks consists of nine tanks: 241-BY-112; 241-C-108, -111, and -112; 241-T-107; 241-TX-118; and 241-TY-101, -103, and -104. These tanks were divided into three groups. Groups A and B are made up of tanks with similar waste heights and temperatures. Group $C$ contained two tanks dissimilar from the others. Analyses were conducted to determine the upper and lower bounds of the heat load; the results are shown in Table 2-1.

Table 2-1. Estimated Tank Heat Loads.

\begin{tabular}{|c|c|c|c|c|}
\hline Tank & Lower Bound & Nominal & Upper Bound & Group \\
\hline $241-\mathrm{C}-108$ & $1.0 \mathrm{~kW}$ & $1.6-2.1 \mathrm{~kW}$ & $3.5 \mathrm{~kW}$ & A \\
\hline $241-\mathrm{C}-111$ & $1.0 \mathrm{~kW}$ & $1.6-2.1 \mathrm{~kW}$ & $3.5 \mathrm{~kW}$ & A \\
\hline $241-\mathrm{C}-112$ & $1.0 \mathrm{~kW}$ & $1.6-2.1 \mathrm{~kW}$ & $3.5 \mathrm{~kW}$ & A \\
\hline $241-\mathrm{T}-107$ & $0.2 \mathrm{~kW}$ & $0.5-1.0 \mathrm{~kW}$ & $1.7 \mathrm{~kW}$ & B \\
\hline $241-\mathrm{TY}-101$ & $0.2 \mathrm{~kW}$ & $0.5-1.0 \mathrm{~kW}$ & $1.7 \mathrm{~kW}$ & B \\
\hline $241-\mathrm{TY}-103$ & $0.2 \mathrm{~kW}$ & $0.5-1.0 \mathrm{~kW}$ & $1.7 \mathrm{~kW}$ & B \\
\hline $241-\mathrm{TY}-104$ & $0.2 \mathrm{~kW}$ & $0.5-1.0 \mathrm{~kW}$ & $1.7 \mathrm{~kW}$ & B \\
\hline $241-\mathrm{BY}-112$ & $0.9 \mathrm{~kW}$ & $1.3-1.5 \mathrm{~kW}$ & $2.6 \mathrm{~kW}$ & C \\
\hline $241-\mathrm{TX}-118$ & $0.9 \mathrm{~kW}$ & $1.3-1.5 \mathrm{~kW}$ & $2.6 \mathrm{~kW}$ & C \\
\hline
\end{tabular}

Only two tanks could be analyzed for thermal conductivity; the results are shown in Table 2-2.

Table 2-2. Estimated Thermal Conductivity.

\begin{tabular}{|c|l|c|}
\hline Tank & Material & $\begin{array}{c}\text { Thermal Conductivity } \\
\left(\mathrm{W} / \mathrm{m}-{ }^{\circ} \mathrm{C}\right)\end{array}$ \\
\hline 241-BY-112 & Saltcake & $0.69-1.21$ \\
\hline 241-TX-118 & Sludge & $1.21-1.39$ \\
\hline
\end{tabular}


This page intentionally left blank. 


\subsection{DESCRIPTION OF MODEL}

\subsection{MODEL CONFIGURATION}

Development of the model and technique used is described in detail in McLaren (1993), and is briefly described here. The model was created for use with the HEATING7 code using regions describing the tank, the contents of the tank, and the surrounding soil. The tank was modeled using data from the tank drawings, with a stepped floor, cylindrical sides, and stepped roof. Because of symmetry, the tank was modeled in cylindrical coordinates, in two dimensions only, vertically from the soil surface to the water table, and radially from the centerline to the outer boundary of the model. Figure 3-1 shows the model of tank 214-BY-112 as developed for the HEATING7 code.

The model used 7 regions inside the tank to describe the airspace, 11 regions to describe the concrete tank bottom, sides and dome, and 15 regions outside the tank to describe the soil surrounding the tank. The regions inside the tank describing the waste were in the form of layers. The characteristics of the waste regions changed during analysis of the tank because the waste volume within the tank changed over time, specifically when the tank was saltwell pumped. The material descriptions of these regions were changed by creating a new model at the time stabilization was complete.

The physical boundaries of the model were: 1) the soil surface with a forced convection heat transfer coefficient for heat rejecting to a constant soil temperature of $12.2^{\circ} \mathrm{C}$; 2) a boundary at $61.0 \mathrm{~m}$ below the surface with heat rejecting to a constant temperature of $\left.12.8^{\circ} \mathrm{C} ; 3\right)$ the centerline of the tank, projected up to the surface and down to the $61.0-\mathrm{m}$ boundary; and 4 ) a reflective boundary at $17.5 \mathrm{~m}$ radially.

\subsection{HEAT TRANSFER MODELING}

Heat transfer within the waste itself was assumed to be by conduction. While convection occurs within the liquid regions of the waste, this method of heat transfer was accounted for by using a high thermal conductivity $\left(2.60 \mathrm{~W} / \mathrm{m}-{ }^{\circ} \mathrm{C}\right)$ within these regions. Radiative and convective heat transfer was assumed within the tank airspace, from the waste surface to the domed top of the tank. Breathing of the tank due to atmospheric pressure changes was not taken into account because studies of the volume exchange by this mechanism ( 3 to 9 tank volumes per year) indicated that the heat loss was too low to be significant. Heat transfer from the tank to the soil boundaries was modeled by conduction through the soil surrounding the tank. 
Figure 3-1. Typical HEATING7 Model of 2,839,000-Liter (750,000-Gallon)

Waste Storage Tank (Dimensions in Feet).

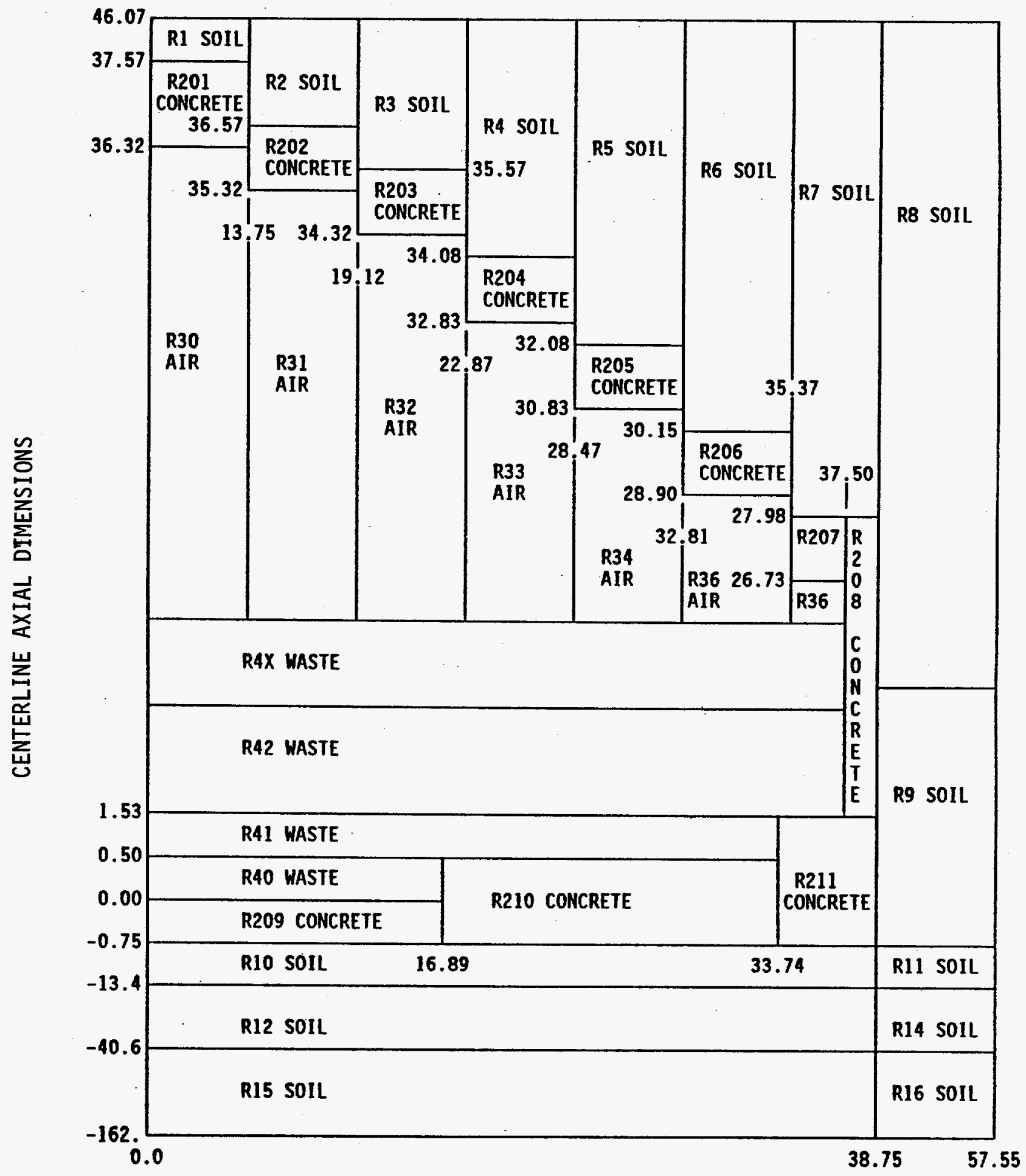

RADIAL DIMENSIONS 


\subsection{SOIL CONDUCTIVITY}

Use of a thermal model to estimate heat loads in the single-shell waste storage tanks requires a knowledge of the thermal conductivity of the soil surrounding the tanks. Analyses have shown that the primary path of heat rejection from the tank is through the soil directly above the tank to the atmosphere, with a considerable fraction traveling through the soil around and under the tank upwards to the atmosphere, and only a small fraction going to the water table below the tank. Parameter studies have shown that the soil thermal conductivity is the most important parameter in making the heat load estimation.

An important factor in determining soil conductivity is the amount of moisture in the soil. Hanford Site soils have considerable variability in the lithological description, or soil types, ranging from fine sand to coarse gravel. Each of these soil types shows different moisture retention properties; as a result, the thermal conductivity of the soils surrounding the single-shell waste storage tanks is not well known.

Until recently, the only laboratory analyses of soil conductivities were conducted in 1975 on SX farm soils, with results that are open to question. In 1993, laboratory analyses of thermal conductivities and heat capacities of soils were conducted at the proposed site for the Multi-Function Waste Facility storage tanks, using a specified density and under varying conditions of temperature (Poppendiek et al. 1993). The results from the more recent analyses of soil conductivities are used in the tank heat load analyses in this report.

Two basic soil types have been identified from borehole samples: a "shallow" type of soil from the surface to $37 \mathrm{~m}$ below the surface, called the Pleistocene deposits, and a "deep" type of soil, which is more compacted, called the Hanford Formation, which lies below the upper 37-m layer and extends to below to the water table. These soil types originate from the various geologic periods of deposition.

Moisture in the soils surrounding the tanks and deep under the tanks has been measured to be approximately $4 \mathrm{wt} \%$ in a band from the surface to a depth of $9 \mathrm{~m}$. Below $9 \mathrm{~m}$, the soil moisture has been measured to be approximately $2 \mathrm{wt} \%$. The lower bounds of these moistures are taken to be $20 \%$ lower than the nominal values. The upper bounds are taken to be $20 \%$ higher than the nominal value for soils below $9 \mathrm{~m}$, and to be $8 \mathrm{wt} \%$ for soils above $9 \mathrm{~m}$.

The soil regions used in the model are: 1) a layer of shallow-type soil from the surface to $9 \mathrm{~m}$ below the surface, at a nominal moisture of $4 \mathrm{wt \%}$; 2) a layer of shallow-type soil from $9 \mathrm{~m}$ below the surface to $37 \mathrm{~m}$ below the surface at a nominal moisture content of $2 \mathrm{wt} \%$; and 3) a layer of deep-type soil from $37 \mathrm{~m}$ below the surface to the water table at $61 \mathrm{~m}$ below the surface. Note that the tank bottom is below the 9-m depth, so the tank is surrounded by soil with two different moisture contents, and is above a second type of soil. The values of soil conductivity used in these analyses are summarized in Tables 3-1 to 3-3. No limits of accuracy were stated in the analysis report, but these values are considered to be 
accurate within $10 \%$. The values tabulated below include the effects of the conductivity accuracy and soil moisture accuracy.

Table 3-1. Nominal Soil Conductivity Values $\left(\mathrm{W} / \mathrm{m}-{ }^{\circ} \mathrm{C}\right)$.

\begin{tabular}{|l|c|c|c|c|}
\hline $\begin{array}{c}\text { Soil } \\
\text { Regions }\end{array}$ & $\begin{array}{c}\text { Moisture } \\
(\text { nominal })\end{array}$ & $\begin{array}{c}\text { Conductivity } \\
\left(12.8^{\circ} \mathrm{C}\right)\end{array}$ & $\begin{array}{c}\text { Conductivity } \\
\left(43.3^{\circ} \mathrm{C}\right)\end{array}$ & $\begin{array}{c}\text { Conductivity } \\
\left(76.7^{\circ} \mathrm{C}\right)\end{array}$ \\
\hline Shallow & $4 \mathrm{w} / \mathrm{o}$ & .929 & .947 & .99 \\
\hline Shallow & $2 \mathrm{w} / \mathrm{o}$ & .692 & .713 & .74 \\
\hline Deep & $2 \mathrm{w} / \mathrm{o}$ & 1.02 & 1.06 & 1.09 \\
\hline
\end{tabular}

Table 3-2. Upper Bound Soil Conductivity Values $\left(\mathrm{W} / \mathrm{m}-{ }^{\circ} \mathrm{C}\right)$.

\begin{tabular}{|l|c|c|c|c|}
\hline $\begin{array}{c}\text { Soil } \\
\text { Regions }\end{array}$ & $\begin{array}{c}\text { Moisture } \\
\text { (nominal) }\end{array}$ & $\begin{array}{c}\text { Conductivity } \\
\left(12.8^{\circ} \mathrm{C}\right)\end{array}$ & $\begin{array}{c}\text { Conductivity } \\
\left(43.3^{\circ} \mathrm{C}\right)\end{array}$ & $\begin{array}{c}\text { Conductivity } \\
\left(76.7^{\circ} \mathrm{C}\right)\end{array}$ \\
\hline Shallow & $4 \mathrm{w} / \mathrm{o}$ & 1.43 & 1.45 & 1.50 \\
\hline Shallow & $2 \mathrm{w} / \mathrm{o}$ & 0.822 & 0.843 & 0.879 \\
\hline Deep & $2 \mathrm{w} / \mathrm{o}$ & 1.27 & 1.31 & 1.35 \\
\hline
\end{tabular}

Table 3-3. Lower Bound Soil Conductivity Values $\left(\mathrm{W} / \mathrm{m}-{ }^{\circ} \mathrm{C}\right)$.

\begin{tabular}{|l|c|c|c|c|}
\hline $\begin{array}{c}\text { Soil } \\
\text { Regions }\end{array}$ & $\begin{array}{c}\text { Moisture } \\
\text { (nominal) }\end{array}$ & $\begin{array}{c}\text { Conductivity } \\
\left(12.8^{\circ} \mathrm{C}\right)\end{array}$ & $\begin{array}{c}\text { Conductivity } \\
\left(43.3^{\circ} \mathrm{C}\right)\end{array}$ & $\begin{array}{c}\text { Conductivity } \\
\left(76.7^{\circ} \mathrm{C}\right)\end{array}$ \\
\hline Shallow & $4 \mathrm{w} / \mathrm{o}$ & .765 & .781 & .813 \\
\hline Shallow & $2 \mathrm{w} / \mathrm{o}$ & .573 & .592 & .611 \\
\hline Deep & $2 \mathrm{w} / \mathrm{o}$ & .838 & .865 & .903 \\
\hline
\end{tabular}

\subsection{ASSUMPTIONS}

\subsubsection{Atmosphere}

The atmospheric air temperature was assumed to be constant over the entire time period studied. An average of temperatures over $60+$ years was used in the model. This average was $12.2^{\circ} \mathrm{C}$. Meteorological data are included as Appendix A.

\subsubsection{Geometry}

The amount of soil surrounding each tank varies depending upon the position of the tank in the farm. The soil surrounding a tank wholly within the farm is considered to be in the shape of a square when viewed vertically, and in the shape of a rectangle with the tank offset 
from the center for those tanks on the edges of the farm. The actual geometry was simplified by assuming that the soil around each tank was in the shape of a cylinder and equal in volume to the amount surrounding a tank completely enclosed within the farm. The dimensions of this cylinder were $17.5 \mathrm{~m}$ in radius and $61.0 \mathrm{~m}$ in height.

\subsection{INPUT DATA AND UNCERTAINTIES}

The data used for determining the heat load and thermal characteristics of the waste are the temperature readings at various levels within the waste and/or within the airspace of the tank. Temperature measurement error analysis (Scaief 1991) indicates that the temperature readings may have an error of as much as $\pm 5^{\circ} \mathrm{C}$ under the worst conditions, but usually have an error of only $\pm 1.7^{\circ} \mathrm{C}$. This error is primarily from temperature measurement errors at the reference junction; as a result, temperature errors for a given thermocouple string are almost always in one direction, either plus or minus, but not both. This means the shape of the data curves is accurate and the thermal conductivity errors are not caused by extreme variations in slope of the temperature-vs.-height curve.

Other data used for the analysis are the tanks' fill/transfer and temperature histories (Anderson 1990). The fill/transfer histories are generally known, but the early temperature histories are unknown. This period of unknown or unavailable temperature data ranges from the initial fill (ca. 1955) to as late as 1989 in some cases, but usually to about 1974. Prior to 1992, all temperature data were recorded by hand. After 1992, the thermocouples in the tanks were progressively placed on the Tank Monitoring and Control System (TMACS). As a result of this gap in temperature history, considerable error can exist between the actual and the calculated heat load at various times between 1957 and 1983. The intent in developing this history is to heat the soil surrounding the tank to the proper temperature at stabilization; therefore, this error does not have much effect on the solutions at the end of the period studied (1984 to 1993). Parametric analyses have shown that sizeable errors can exist between the computed and actual temperatures within the tank with little $\left(<0.5^{\circ} \mathrm{C}\right)$ change in the soil temperatures. This insensitivity allows good analyses using estimated data.

\subsection{HEAT LOAD DETERMINATION METHOD}

An iterative process is used to determine the tanks' heat loads. The analysis is conducted in two phases. The first phase models the tank from the time of initial filling to the time it was saltwell pumped, and the second phase models the tank from the time of saltwell pumping to the present. Two phases are required because the HEATING7 code does not allow changes in the region dimensions during a given computer run, even with restarts. The purpose of Phase $I$ is to preheat the soil to the proper temperatures and temperature distribution just prior to saltwell pumping. Phase II starts at this point with the current tank configuration and develops the present heat load of the tank. This complexity is necessary because the 
time constant of the soil surrounding the tank is long compared to the time span studied. The soil temperatures had not approached equilibrium at the end of Phase I, and they necessarily are an important factor in determining the final heat load, as reported in McLaren (1993).

In Phase I, a model of the tank prior to stabilization is created. The input data are the tank's fill/transfer history and temperatures. The process starts by developing the fill/transfer history data into a plot to determine the average contents and region heights. Then the salient points of the temperature history are identified. When this process has been completed, a heat load-vs.-time curve is developed. These temperature histories require that the heat load-vs.-time curves be stepped at various times. This curve is input into the model and a transient problem is computed and analyzed. The intent is to match the temperatures at the salient points previously determined. This requires altering the initial heat load of the tank and the heat load-vs.-time curves to accomplish the match. The purpose of this phase is to get a fairly accurate preheat of the soil surrounding the tank at the time just before saltwell pumping. When this has been accomplished, the second phase of the analysis begins.

Phase II begins by altering the model to describe the contents of the tank after the free liquid has been removed. A soil temperature map at the time of saltwell pumping is determined from Phase I. This map is input into the model as a series of normalized temperaturevs.-position curves. The temperature-vs.-height data of the waste at the beginning of this second phase is input as an initial condition and the iterative process begins again, this time from the time of saltwell pumping to the present.

An estimation of the heat load and heat generation distribution is made based on the shape and values of the final temperature-vs.-height curve. An estimate of the thermal conductivity of the waste is also made from the shape of the final temperature-vs.-height curve. These estimates are input into the model and a computer prediction of the waste temperatures is generated. The results of the prediction are compared against the final temperature data. The estimates of the tank heat load, heat generation distribution, and waste thermal conductivities are adjusted and the process repeated until the computer predictions match the data. A close match between the predicted temperatures and the data is necessary at the end of the problem in order to develop as good a prediction of heat load and waste thermal conductivity as possible; however, an exact match is not required.

\subsection{ERROR BOUNDS}

The error bounds of the analysis are determined by running two sets of Phase I and Phase II analyses with the temperature data skewed to the limits of accuracy described in Section 3.5, and the soil conductivities skewed to their accuracy limits as described in Section 3.3.

The lower bound is determined by using the lower soil conductivity values (Table 3-3) for both the Phase I and Phase II analyses and running the Phase I analysis to match the assumed 
temperature profile over time with the temperature values skewed $1.7^{\circ} \mathrm{C}$ high. The resulting temperature map is input into the Phase II model and the Phase II analysis is run. The initial waste temperatures are skewed $1.7^{\circ} \mathrm{C}$ high and the Phase II analysis is run to match the final temperature data, which are skewed $1.7^{\circ} \mathrm{C}$ low. This high-to-low temperature difference allows the greatest heat loss from the tank while staying within the accuracy limits of the data.

The upper bound analyses are run in the same way, with the temperature skews in the opposite direction, and with the upper soil conductivity values (Table 3-2) used in both the Phase I and Phase II analyses. The Phase I analysis is run to match the assumed temperature profile skewed $1.7^{\circ} \mathrm{C}$ low. The Phase II analysis is run with the initial waste temperatures skewed $1.7^{\circ} \mathrm{C}$ low to match the final temperature data skewed $1.7^{\circ} \mathrm{C}$ high. These conditions allow the least heat loss from the tank while staying within the accuracy limits of the data. 
This page intentionally left blank. 


\subsection{RESULTS}

The tanks analyzed in Group II were 241-BY-112; 241-C-108, -111, and -112; 241-T-107; 241-TX-118; and 241-TY-101, -103, and -104. Table A-2 of WHC-EP-0182-63, Tank Farm Surveillance and Waste Status Report for June 1993 (Hanlon 1993), shows that many of the tanks have similar waste heights and temperatures. Because of these similarities, the tanks were divided into three groups. Group A consisted of tanks 241-C-108, -111, and -112. These tanks were grouped because they are 1,893,000-liter (500,000-gallon) tanks and because of their similar temperatures and waste heights. All the other tanks studied have 2,839,000-liter (750,000-gallon) capacities. Group B consisted of tanks 241-T-107, 241-TY-101, -103, and -104. These tanks were also grouped because of similarity in their temperature and waste height. Group C consisted of tanks 241-BY-112 and 241-TX-118, which were not similar to any of the other tanks because they have more waste in them than the others, and the waste is slightly higher in temperature.

Each group was evaluated to determine the tanks with the highest and lowest heat loads. This evaluation was performed by comparing waste height and maximum temperatures for the tanks within a group. With waste heights equal, the tank with the higher temperatures will have the higher heat load. With equal temperatures, the tank with the lower waste height will have the higher head load. The tanks with the highest and lowest heat loads were the only two tanks analyzed in a group; the remaining tanks in the group have heat loads within these extremes. The tanks' temperatures and levels, taken from Hanlon (1993), are shown in Table 4-1 below.

Table 4-1. Studied Tanks Grouped by Waste Level and Temperature.

\begin{tabular}{|l|c|c|}
\hline \multicolumn{1}{|c|}{ Tank } & Waste Height & Maximum Temperature \\
\hline $241-\mathrm{C}-108$ & $79 \mathrm{~cm}$ & $21.7^{\circ} \mathrm{C}$ \\
\hline $241-\mathrm{C}-111$ & $71 \mathrm{~cm}$ & $21.1^{\circ} \mathrm{C}$ \\
\hline $241-\mathrm{C}-112$ & $114 \mathrm{~cm}$ & $25.0^{\circ} \mathrm{C}$ \\
\hline \hline $241-\mathrm{T}-107$ & $185 \mathrm{~cm}$ & $17.2^{\circ} \mathrm{C}$ \\
\hline $241-\mathrm{TY}-101$ & $127 \mathrm{~cm}$ & $17.8^{\circ} \mathrm{C}$ \\
\hline $241-\mathrm{TY}-103$ & $168 \mathrm{~cm}$ & $20.0^{\circ} \mathrm{C}$ \\
\hline $241-\mathrm{TY}-104$ & $163 \mathrm{~cm}$ & $17.8^{\circ} \mathrm{C}$ \\
\hline \hline $241-\mathrm{BY}-112$ & $287 \mathrm{~cm}$ & $30.6^{\circ} \mathrm{C}$ \\
\hline $241-\mathrm{TX}-118$ & $340 \mathrm{~cm}$ & $24.4^{\circ} \mathrm{C}$ \\
\hline
\end{tabular}




\subsection{GROUP A}

Group A consisted of tanks 241-C-108, -111, and -112. Tank 241-C-111 was analyzed for nominal conditions and for lower bound conditions. Tank 241-C-112 was analyzed for nominal conditions and for upper bound conditions. The heat load of tank 241-C-108 is within the upper and lower bound estimates. The results of these analyses are shown in Table 4-2.

Table 4-2. Results of Group A Analysis.

\begin{tabular}{|c|c|c|c|}
\hline Tank & Upper Bound & Nominal & Lower Bound \\
\hline $241-\mathrm{C}-112$ & $3.5 \mathrm{~kW}$ & $2.1 \mathrm{~kW}$ & \\
\hline $241-\mathrm{C}-111$ & & $1.6 \mathrm{~kW}$ & $1.0 \mathrm{~kW}$ \\
\hline
\end{tabular}

\subsubsection{Analysis of Tank 241-C-111}

Tank 241-C-111 contains only $71 \mathrm{~cm}$ of waste, and only one thermocouple is in the waste. No useful temperature data exist for the tank prior to 1989. The tank's fill/transfer history shows no transfers into the tank after June 1964 except for one small transfer in March 1974 (Figure 4-1). Free liquid was removed in 1976. From the temperature history of tank 241-C-112, it appears that the maximum temperature in both tanks was about $35^{\circ} \mathrm{C}$ just prior to saltwell pumping.

The Phase I analysis started with the soil surrounding the tank at $12.8^{\circ} \mathrm{C}$ and the waste at $37.8^{\circ} \mathrm{C}$, ran from October 1946 to July 1976 , and matched a final maximum temperature in the waste of $35^{\circ} \mathrm{C}$. Phase II ran from January 1977 to January 1994 . It started with a waste temperature of $35{ }^{\circ} \mathrm{C}$ and ended with a waste temperature of $22.2^{\circ} \mathrm{C}$. Because of the lack of temperature data, no estimate of the waste's thermal conductivity could be made. The value used for the analysis was $0.95 \mathrm{~W} / \mathrm{m}-{ }^{\circ} \mathrm{C}$, based on previous work.

\subsubsection{Analysis of Tank 241-C-112}

The fill/transfer history of this tank is similar to that of 241-C-111, and is shown as Figure 4-2. The temperature data history of this tank is shown as Figure 4-3. As can be seen, a gap exists in the temperature data from August 1983 to October 1989. Data during this period are not available, for reasons that are not fully determined as yet. This tank has a thermocouple deep in the waste and another just below the surface. From the temperature data, it appears that the temperature of the waste in 1976 was about $35^{\circ} \mathrm{C}$. 
Figure 4-1. Tank 241-C-111 Fill/Transfer History.

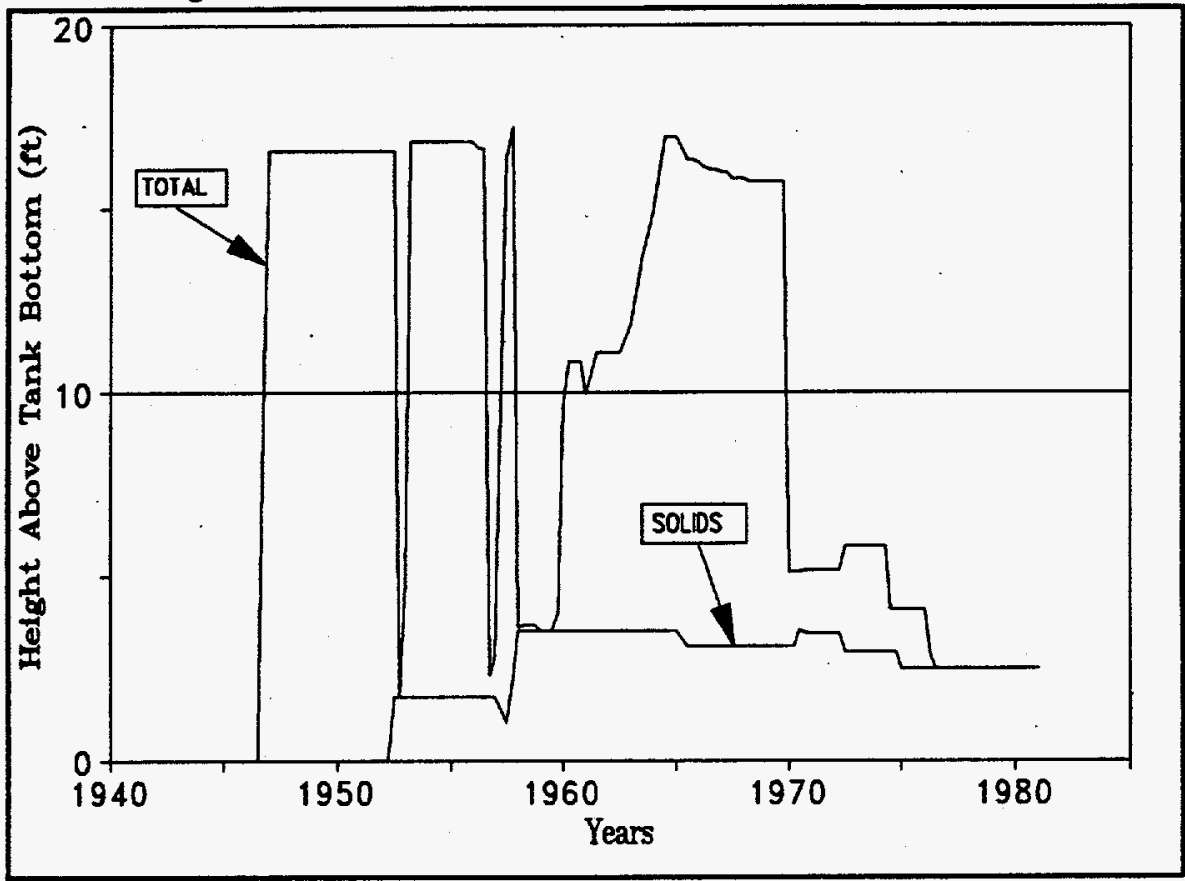

Figure 4-2. Tank 241-C-112 Fill/Transfer History.

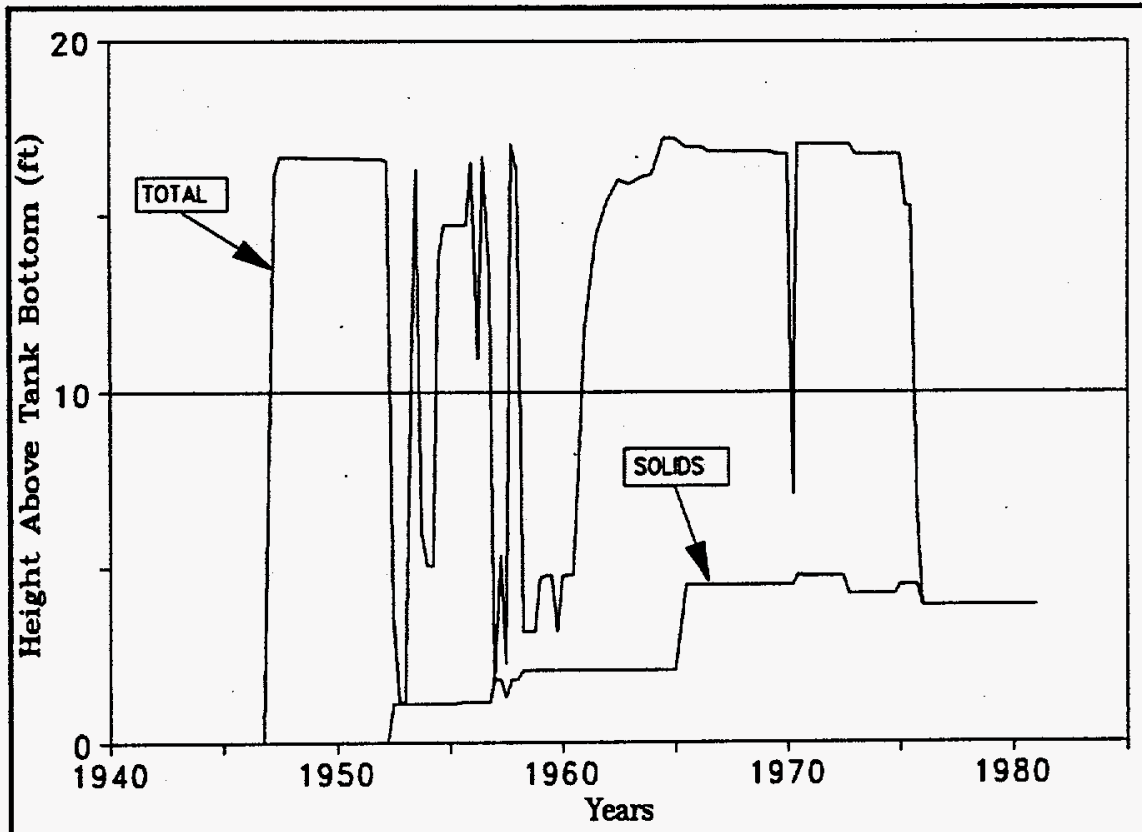


Figure 4-3. Tank 241-C-112 Maximum Temperature Data History.

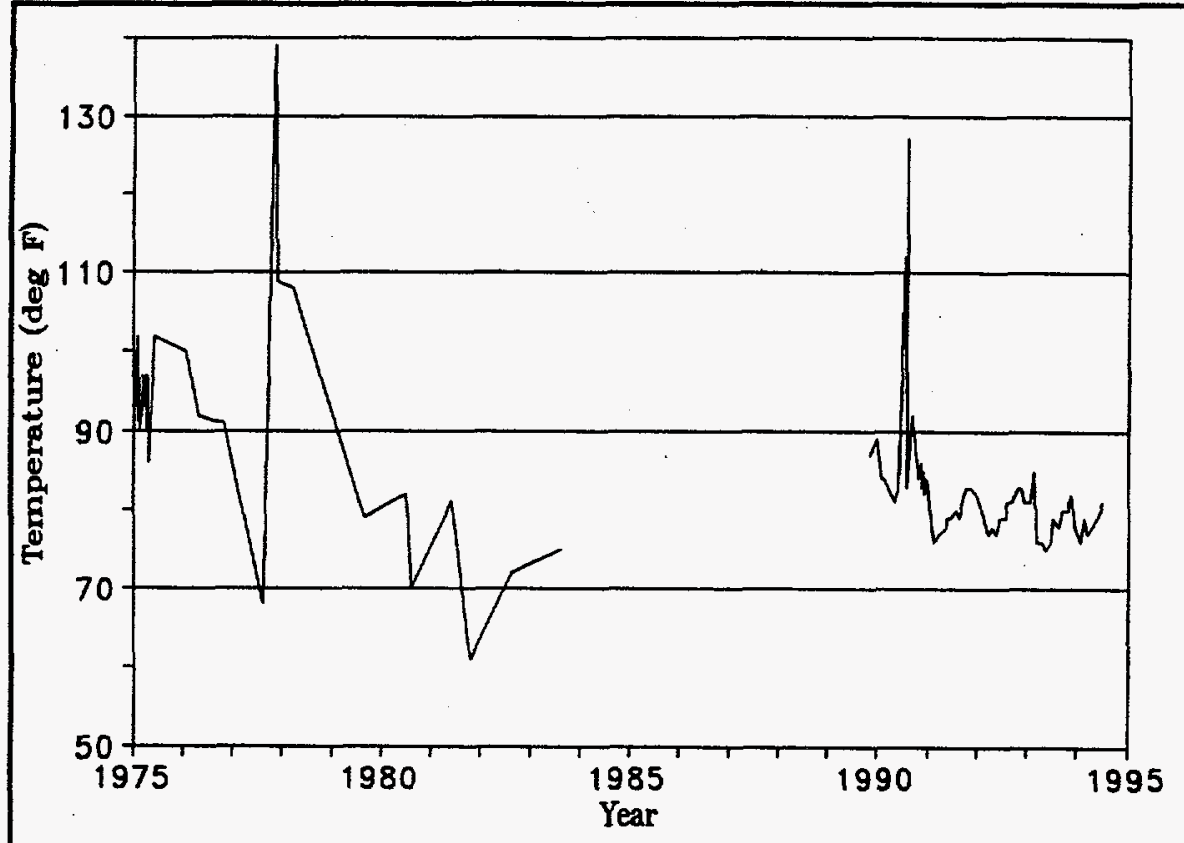

The Phase I analysis of Tank 241-C-112 was run from January 1947 to January 1976 . It started with the soil surrounding the tank at $12.8^{\circ} \mathrm{C}$ and the waste temperature at $37.8^{\circ} \mathrm{C}$, and was run to match a waste temperature in January 1976 of $35^{\circ} \mathrm{C}$. The Phase II analysis was run from August 1976 to December 1993, and was run to match a waste surface temperature of $25.6^{\circ} \mathrm{C}$. A waste conductivity of $2.16 \mathrm{~W} / \mathrm{m}-{ }^{\circ} \mathrm{C}$ was estimated. Because there were only two points in the waste that could be used for thermal conductivity estimations, the value is considered approximate.

\subsection{GROUP B}

Group B consisted of tank 241-T-107 and tanks 241-TY-101, -103, and -104. Tank 241-TY-104 was analyzed for nominal conditions and lower bound conditions. Tank 241-TY-103 was analyzed for nominal conditions and upper bound conditions. The results of these analyses are shown in Table 4-3.

Table 4-3. Results of Group B Analysis.

\begin{tabular}{|c|c|c|c|}
\hline Tank & Upper Bound & Nominal & Lower Bound \\
\hline $241-$ TY-103 & $1.7 \mathrm{~kW}$ & $0.95 \mathrm{~kW}$ & \\
\hline $241-$ TY-104 & & $0.51 \mathrm{~kW}$ & $0.22 \mathrm{~kW}$ \\
\hline
\end{tabular}




\subsubsection{Analysis of Tank 241-TY-103}

Tank 241-TY-103 seems to have been used mostly for storage of transfers from other tanks; its fill/transfer history is shown in Figure 4-4. The tank was periodically filled with waste that was probably at about $38^{\circ} \mathrm{C}$, so the temperature in October 1973 was about $32^{\circ} \mathrm{C}$. This is an estimate based on previous analyses (McLaren 1994).

The Phase I analysis of Tank 241-TY-103 was run from October 1953 to October 1974 . The Phase I analysis started with the soil surrounding the tank at $12.8^{\circ} \mathrm{C}$, and the waste temperature at $37.8^{\circ} \mathrm{C}$, and was run to match a maximum waste temperature in October 1973 of $32^{\circ} \mathrm{C}$. Phase II was run from March 1977 to December 1993. Initial waste temperatures came from March 12, 1977 data, and the problem was run to match December 21, 1993 data. A waste conductivity of $1.73 \mathrm{~W} / \mathrm{m}-{ }^{\circ} \mathrm{C}$ was estimated. There are only two thermocouples in the waste, so this value is considered approximate.

Figure 4-4. Tank 241-TY-103 Fill/Transfer History.

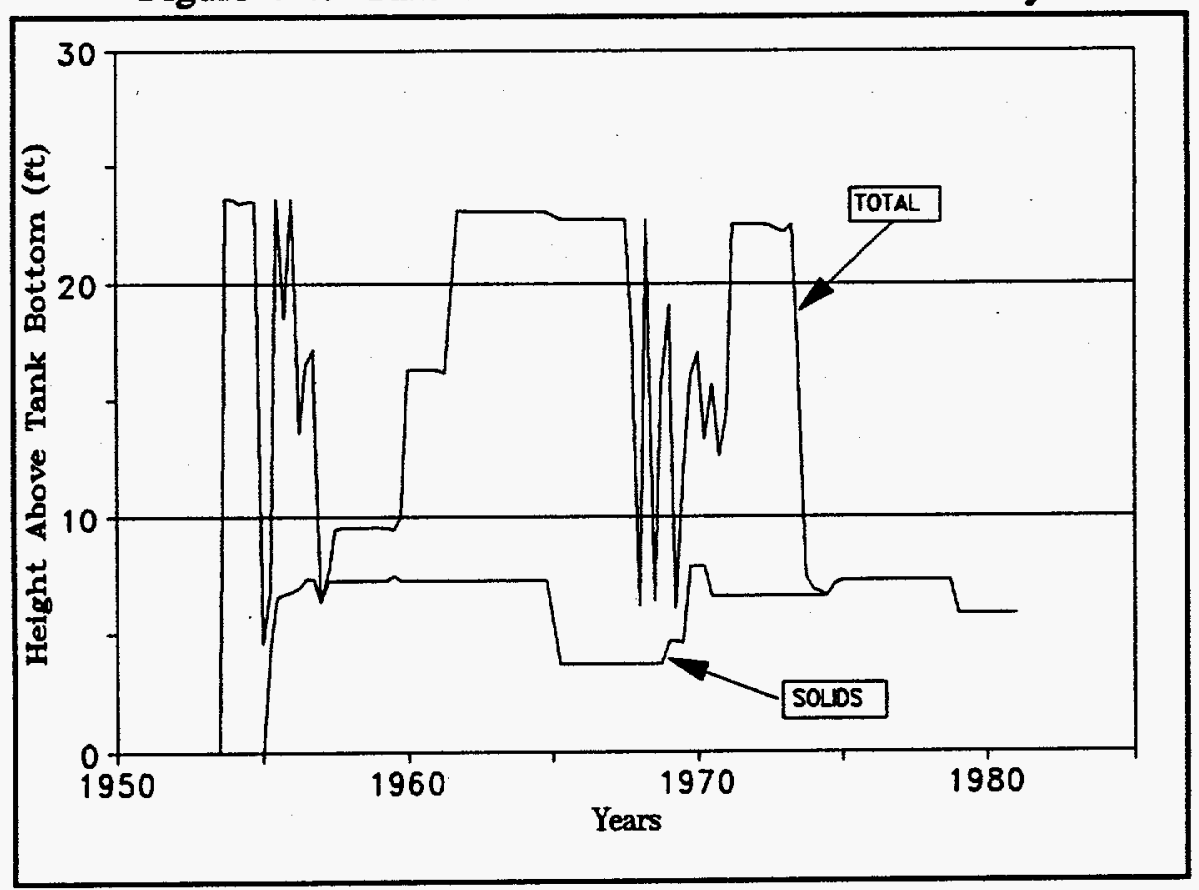

\subsubsection{Analysis of Tank 241-TY-104}

The fill/transfer history of this tank indicates that it had four big fills, with subsequent cooling periods (Figure 4-5). The tank's temperature history was created from estimated temperatures, based on the fill/transfer history. This estimated temperature history is shown in Figure 4-6. The temperature values are based on estimates of the waste temperatures from the waste processes and from prior analyses. 
The Phase I analysis of Tank 241-TY-104 was run from January 1954 to January 1981. The Phase II analysis was run from November 1983 to January 1994. Temperature data after 1982 indicate a nearly steady-state condition. The initial waste temperatures were taken from the November 13, 1983 data, and the analysis was run to match January 3, 1994 data. The waste conductivity value used for this analysis was $1.38 \mathrm{~W} / \mathrm{m}-{ }^{\circ} \mathrm{C}$, but the temperature data are such that this value can be considered only approximate.

Figure 4-5. Tank 241-TY-104 Fill/Transfer History.

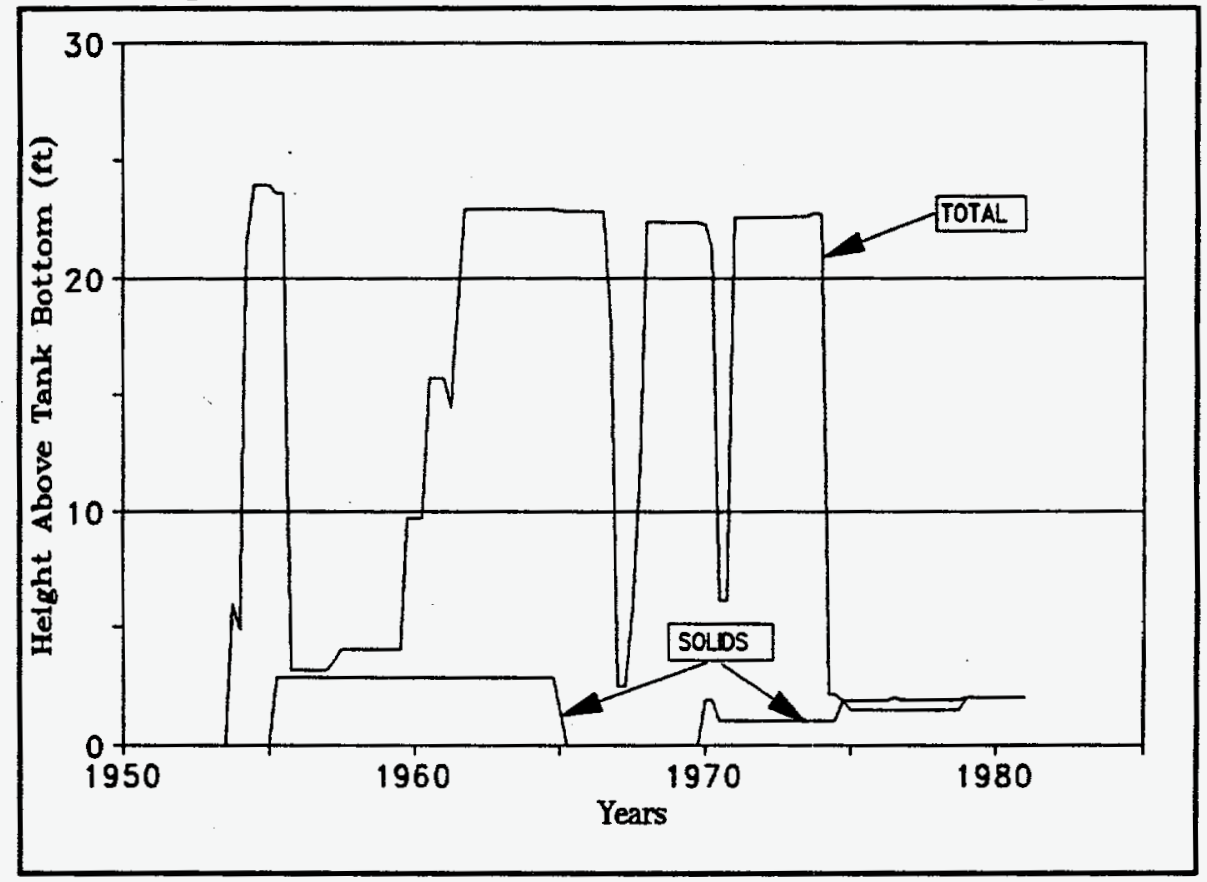


Figure 4-6. Tank 241-TY-104 Estimated Temperature History.

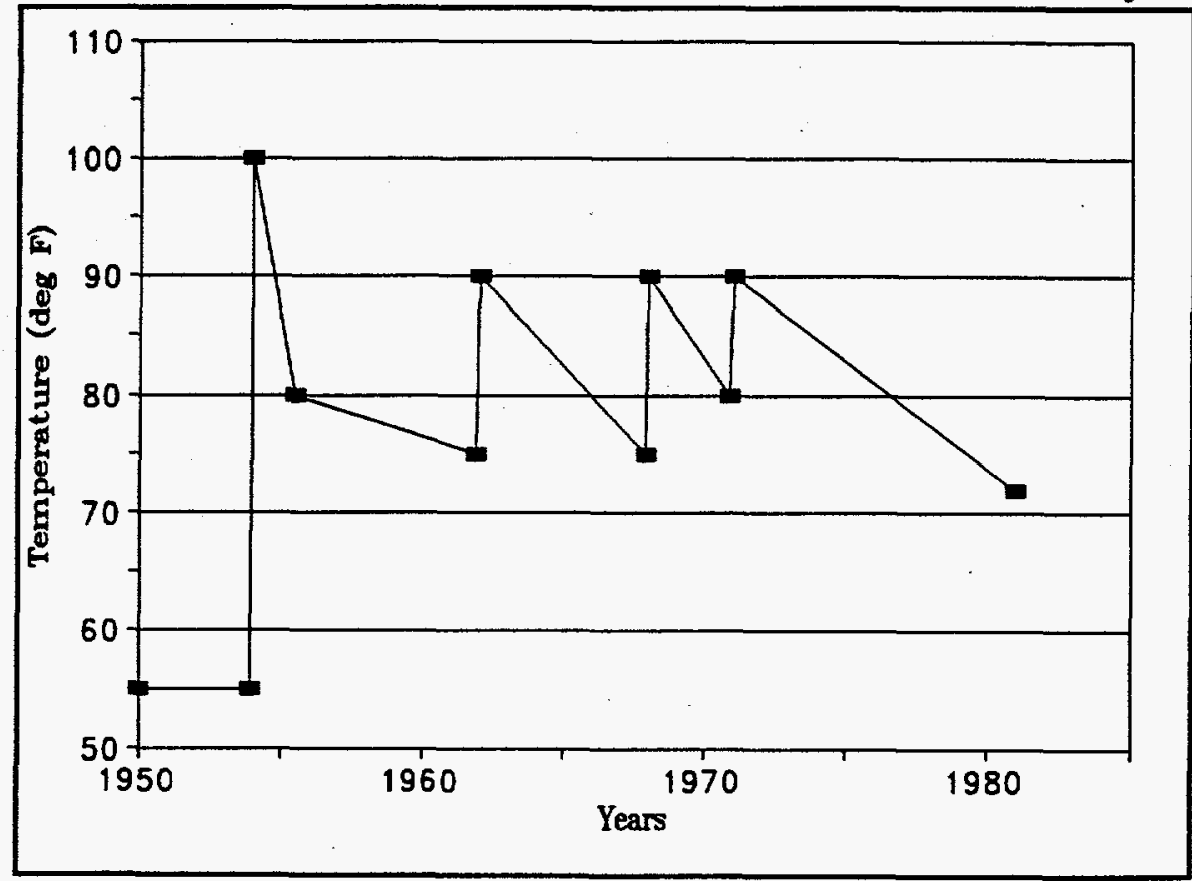

\subsection{GROUP C}

Group C consisted of tanks 241-BY-112 and 241-TX-118. Tank 241-TX-118 was analyzed for nominal and lower bound conditions. Tank 241-BY-112 was analyzed for nominal and upper bound conditions. The results of these analyses are shown in Table 4-4.

Table 4-4. Results of Group C Analysis.

\begin{tabular}{|c|c|c|c|}
\hline Tank & Upper Bound & Nominal & Lower Bound \\
\hline $241-\mathrm{BY}-112$ & $2.6 \mathrm{~kW}$ & $1.5 \mathrm{~kW}$ & \\
\hline $241-\mathrm{TX}-118$ & & $1.3 \mathrm{~kW}$ & $0.88 \mathrm{~kW}$ \\
\hline
\end{tabular}

\begin{tabular}{|c|c|c|}
\hline Tank & $\begin{array}{l}\text { Thermal Conductivity } \\
\left(\mathrm{W} / \mathrm{m}-{ }^{-} \mathrm{C}\right)\end{array}$ & Material in Tank \\
\hline \multirow[b]{2}{*}{ 241-BY-112 } & 1.21 Upper Bound & \multirow[b]{2}{*}{ Saltcake } \\
\hline & 0.69 Nominal & \\
\hline \multirow{2}{*}{ 241-TX-118 } & 1.39 Nominal & \multirow{2}{*}{ Mostly Saltcake } \\
\hline & 1.21 Lower Bound & \\
\hline
\end{tabular}




\subsubsection{Analysis of Tank 241-BY-112}

The fill/transfer history of this tank is shown in Figure 4-7 and indicates that the tank was initially loaded in 1952 and emptied in 1955. It was refilled from July 1956 to 1958 and allowed to stand until October 1967, when it was nearly emptied and then refilled from other tanks. In 1968, the tank contained in-tank solidification (ITS) wastes, and in 1972 was placed in ITS service until July 1976. The tank was saltwell pumped in 1976. It appears to have been fairly hot (around $79^{\circ} \mathrm{C}$ ) at the end of its service.

Figure 4-7. Tank 241-BY-112 Fill/Transfer History.

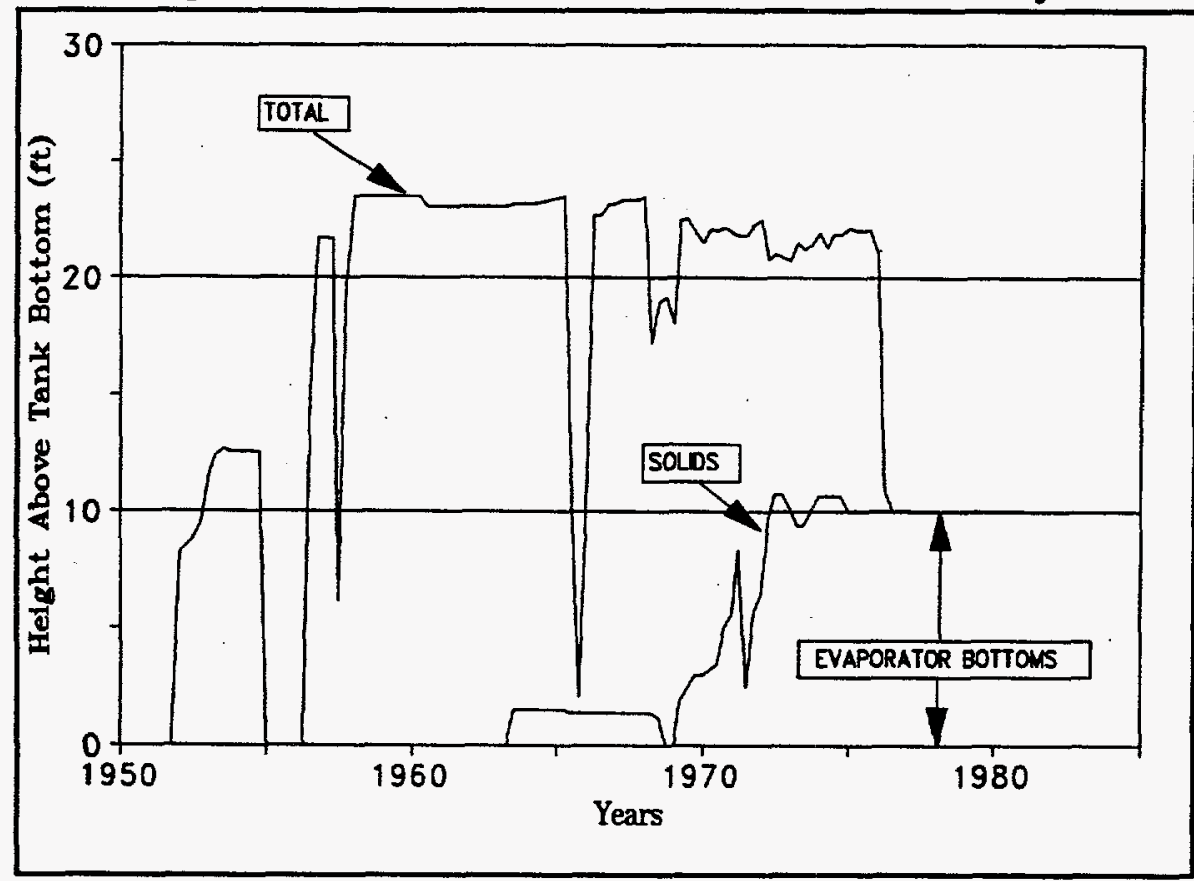

The data indicate that the tank was loaded with hot liquid in July 1956 and allowed to cool somewhat; then ITS liquids were added. To estimate tank 241-BY-112's temperature history, a series of computer runs was made with varying power histories, and the resulting maximum temperatures, taken at various times, were compared against assumed temperatures. Because the only temperatures that could be assumed were at the time of the initial fill and during ITS service, some liberties were taken. The initial fill was assumed to have a temperature of $37.8^{\circ} \mathrm{C}$ in 1952 , and a maximum temperature of $79{ }^{\circ} \mathrm{C}$ was assumed during the ITS service, from January 1969 to July 1976. The temperature was assumed to have decayed to $37.8{ }^{\circ} \mathrm{C}$ by 1981 . To estimate the temperature history between these points, a power history was created; the results of the computer runs are shown on Figure 4-8. In this figure, the temperature at various points in time is shown, along with the estimated power history used to produce it. 
It must be admitted that the temperature history is conjecture, based on engineering judgement and data from analysis of the Group I tanks (McLaren 1994), but it is considered to be a fair estimation of the temperature history.

Figure 4-8. Tank 241-BY-112 Assumed Maximum Temperature History.

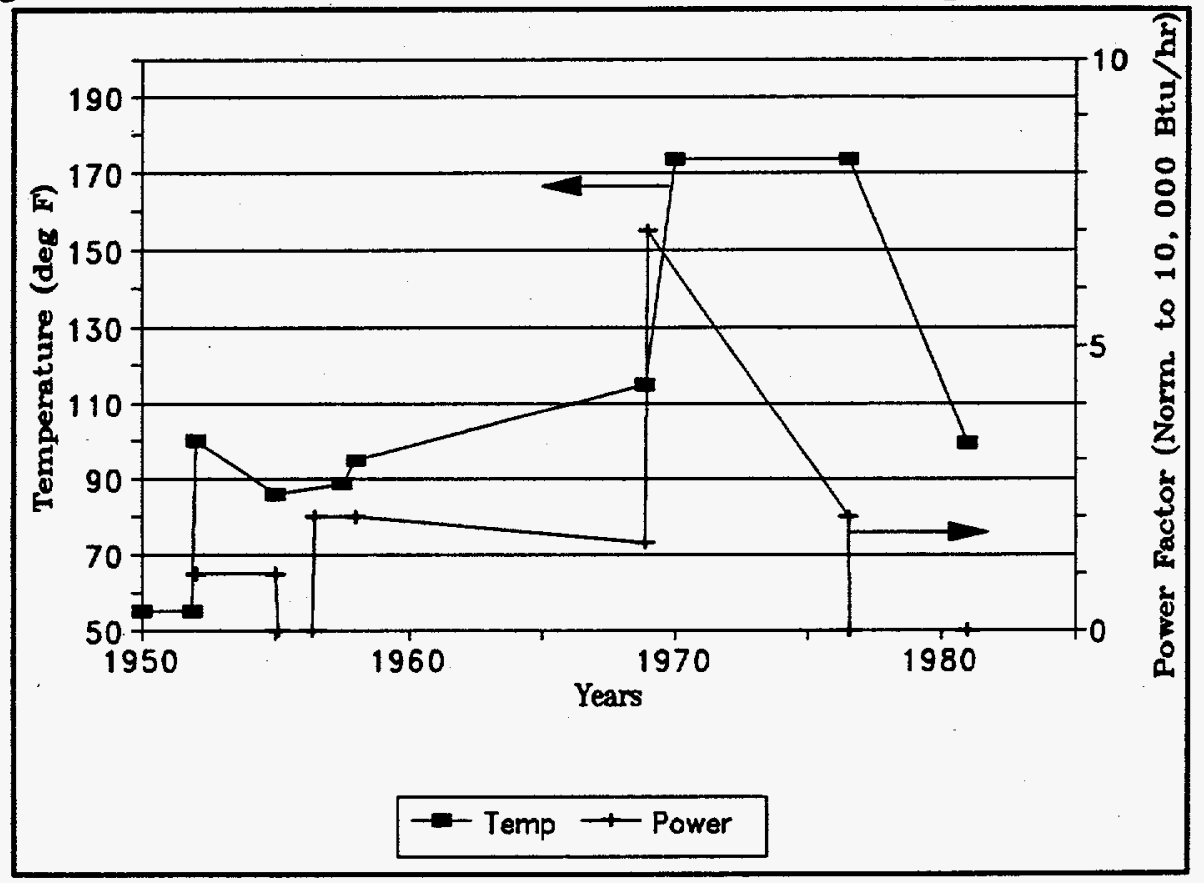

The Phase II analysis of tank 241-BY-112 was run from January 1981 to December 1993. The predicted waste temperatures from the Phase I analysis were used as the waste initial temperatures and the problem was run to match December 23, 1993 data. The thermal conductivity of the waste for the nominal case was estimated to be $0.69 \mathrm{~W} / \mathrm{m}-{ }^{\circ} \mathrm{C}$. The thermal conductivity for the upper bound case was estimated to be $1.21 \mathrm{~W} / \mathrm{m}-{ }^{\circ} \mathrm{C}$. As there are five thermocouples in the waste, these values are considered valid. The fill/transfer history shows that the tank was almost totally emptied prior to being placed into ITS service, and Hanlon (1993) indicates that only $2,000 \mathrm{~g}$ moles of ferrocyanide were originally placed in the tank. Consequently, the tank's contents are nearly all saltcake, which accounts for the low thermal conductivity values.

\subsubsection{Analysis of Tank 241-TX-118}

The fill/transfer history of this tank indicates that it received mostly liquid until late 1964 (Figure 4-9). The tank never received thermally hot liquids; its heat came from radioactive decay. As a result, this tank never became very hot. The earliest temperature data of any use were taken in November 1989 and indicated a maximum temperature of about $25^{\circ} \mathrm{C}$. 
Therefore, the assumed temperature history starts with a waste temperature of $37.8^{\circ} \mathrm{C}$ and a surrounding soil temperature of $12.8^{\circ} \mathrm{C}$. A constant power is applied to the waste such that the final temperature in 1981 is $32.2^{\circ} \mathrm{C}$.

The Phase I analysis of tank 241-TX-118 was run from July 1952 to January 1981. The Phase II analysis started in January 1981 and ran to December 1993. The initial waste temperatures were taken from the Phase I predictions, and the problem was run to match December 21, 1993 data. The thermal conductivity of the waste for the nominal case was estimated to be $1.39 \mathrm{~W} / \mathrm{m}-{ }^{\circ} \mathrm{C}$. The thermal conductivity of the waste for the lower bound case was estimated to be $1.21 \mathrm{w} / \mathrm{m}^{\circ}{ }^{\circ} \mathrm{C}$. There are six thermocouples in the waste; therefore, this estimation is considered valid.

Figure 4-9. Tank 241-TX-118 Fill/Transfer History.

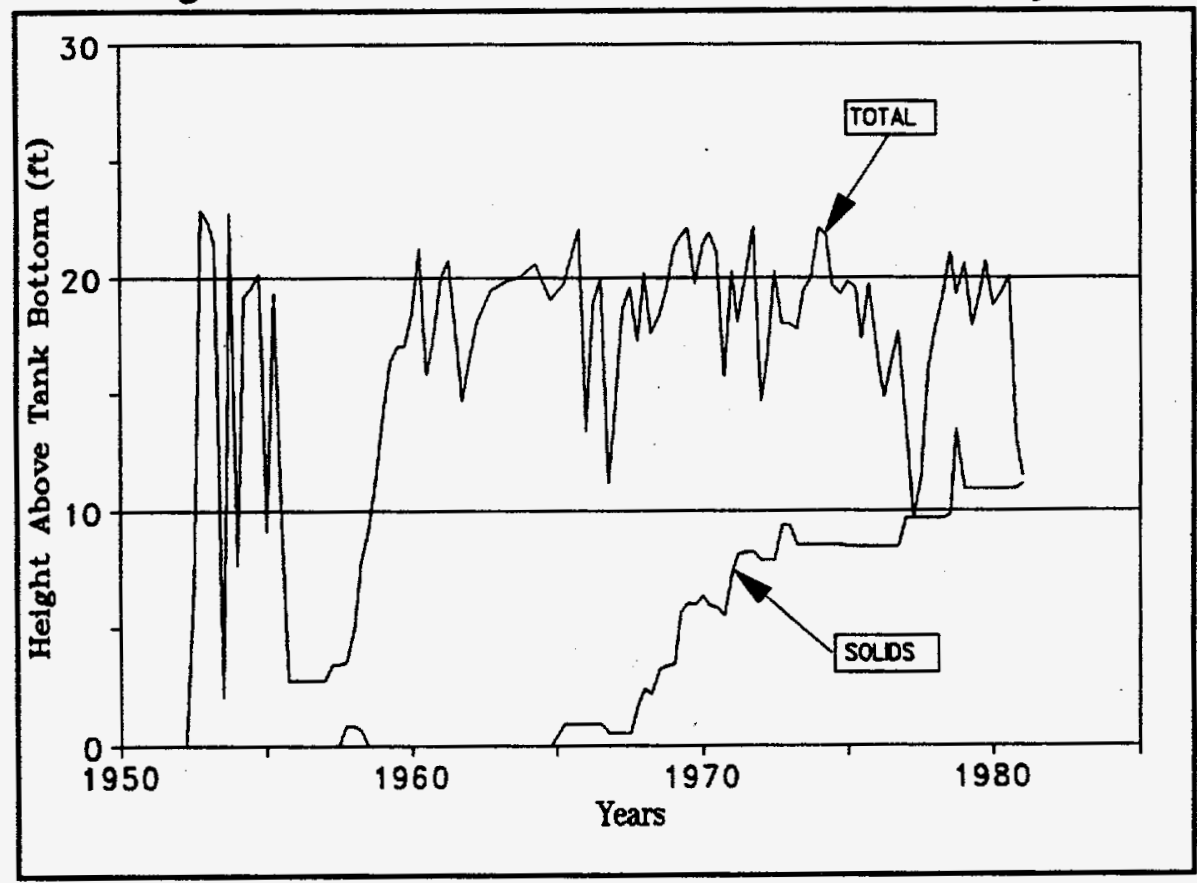




\subsection{COMPILATION OF RESULTS}

This report completes heat load analyses of $18^{*}$ Ferrocyanide Watch List tanks using the updated thermal model. McLaren (1993) covers the development of the model and its application to tank 241-BY-104. McLaren (1994) covers the analysis of the first group of Ferrocyanide Watch List tanks, and this report covers the remaining tanks. Table 5-1 summarizes the results of these analyses.

Table 5-1. Summary of Heat Load Analyses.

\begin{tabular}{|c|c|c|c|c|c|}
\hline Tank & $\begin{array}{l}\text { Lower } \\
\text { Bound }\end{array}$ & Nominal & $\begin{array}{l}\text { Upper } \\
\text { Bound }\end{array}$ & $\begin{array}{l}\text { Crowe } \\
\text { et al. } 1\end{array}$ & $\begin{array}{l}\text { Borsheim } \\
\& \text { Simpson }\end{array}$ \\
\hline 241-BY-103 & $0.7 \mathrm{~kW}$ & $1.2 \mathrm{~kW}$ & $2.1 \mathrm{~kW}$ & $1.6 \mathrm{~kW}$ & $2.3 \mathrm{~kW}$ \\
\hline 241-BY-104 & $1.5 \mathrm{~kW}$ & $2.3 \mathrm{~kW}$ & $3.2 \mathrm{~kW}$ & $2.6 \mathrm{~kW}$ & $2.9 \mathrm{~kW}$ \\
\hline 241-BY-105 & $1.8 \mathrm{~kW}$ & $2.2 \mathrm{~kW}$ & $3.5 \mathrm{~kW}$ & $2.6 \mathrm{~kW}$ & $1.3 \mathrm{~kW}$ \\
\hline 241-BY-106 & $1.9 \mathrm{~kW}$ & $2.5 \mathrm{~kW}$ & $4.2 \mathrm{~kW}$ & $3.0 \mathrm{~kW}$ & $3.2 \mathrm{~kW}$ \\
\hline 241-BY-107 & $1.3 \mathrm{~kW}$ & $1.8 \mathrm{~kW}$ & $3.3 \mathrm{~kW}$ & $2.6 \mathrm{~kW}$ & $2.1 \mathrm{~kW}$ \\
\hline 241-BY-108 & $1.5 \mathrm{~kW}$ & $2.0 \mathrm{~kW}$ & $3.1 \mathrm{~kW}$ & $2.7 \mathrm{~kW}$ & $2.7 \mathrm{~kW}$ \\
\hline 241-BY-110 & $1.5 \mathrm{~kW}$ & $2.1 \mathrm{~kW}$ & $3.2 \mathrm{~kW}$ & $2.0 \mathrm{~kW}$ & $2.9 \mathrm{~kW}$ \\
\hline 241-BY-111 & $0.7 \mathrm{~kW}$ & $1.3 \mathrm{~kW}$ & $2.3 \mathrm{~kW}$ & $1.6 \mathrm{~kW}$ & $0.2 \mathrm{~kW}$ \\
\hline 241-BY-112 & $0.9 \mathrm{~kW}$ & $1.5 \mathrm{~kW}$ & $2.6 \mathrm{~kW}$ & $1.8 \mathrm{~kW}$ & $0.1 \mathrm{~kW}$ \\
\hline 241-C-108 & $1.0 \mathrm{~kW}$ & $1.8 \mathrm{~kW}$ & $3.5 \mathrm{~kW}$ & $1.8 \mathrm{~kW}$ & $0.3 \mathrm{~kW}$ \\
\hline $241-C-109$ & $1.1 \mathrm{~kW}$ & $1.9 \mathrm{~kW}$ & $3.4 \mathrm{~kW}$ & $2.1 \mathrm{~kW}$ & $0.6 \mathrm{~kW}$ \\
\hline 241-C-111 & $1.0 \mathrm{~kW}$ & $1.6 \mathrm{~kW}$ & $3.5 \mathrm{~kW}$ & $1.9 \mathrm{~kW}$ & $0.1 \mathrm{~kW}$ \\
\hline $241-C-112$ & $1.0 \mathrm{~kW}$ & $2.1 \mathrm{~kW}$ & $3.5 \mathrm{~kW}$ & $1.0 \mathrm{~kW}$ & $0.3 \mathrm{~kW}$ \\
\hline 241-T-107 & $0.2 \mathrm{~kW}$ & $0.7 \mathrm{~kW}$ & $1.7 \mathrm{~kW}$ & $0.9 \mathrm{~kW}$ & $0.1 \mathrm{~kW}$ \\
\hline 241-TX-118 & $0.9 \mathrm{~kW}$ & $1.3 \mathrm{~kW}$ & $2.6 \mathrm{~kW}$ & $1.0 \mathrm{~kW}$ & \\
\hline 241-TY-101 & $0.2 \mathrm{~kW}$ & $0.7 \mathrm{~kW}$ & $1.7 \mathrm{~kW}$ & $0.9 \mathrm{~kW}$ & $0.4 \mathrm{~kW}$ \\
\hline 241-TY-103 & $0.2 \mathrm{~kW}$ & $0.5 \mathrm{~kW}$ & $1.7 \mathrm{~kW}$ & $1.2 \mathrm{~kW}$ & $0.6 \mathrm{~kW}$ \\
\hline 241-TY-104 & $0.2 \mathrm{~kW}$ & $1.0 \mathrm{~kW}$ & $1.7 \mathrm{~kW}$ & $0.9 \mathrm{kw}$ & $0.2 \mathrm{~kW}$ \\
\hline
\end{tabular}

${ }^{1}$ Heat load values from Table 7-1 in Crowe et al. (1993)

${ }^{2}$ Heat load values from Table 4-34 in Grigsby et al. (1992)

Tanks 241-BX-102 and -106 were not analyzed because approval to remove them from the Watch List is pending. 
This page intentionally left blank. 


\subsection{REFERENCES}

Anderson, J. D., 1990, A History of the 200 Area Tank Farms, WHC-MR-0132, Westinghouse Hanford Company, Richland, Washington.

Borsheim, G. L., and B. C. Simpson, 1991, An Assessment of the Inventories of the Ferrocyanide Watch List Tanks, WHC-SD-WM-ER-133, Rev. 0, Westinghouse Hanford Company, Richland, Washington.

Crowe, R. D., M. Kummerer, and A. K. Postma, 1993, Estimation of Heat Load in Waste Tanks Using Average Vapor Space Temperatures, WHC-EP-0709, Westinghouse Hanford Company, Richland, Washington.

Grigsby, J. M., D. B. Bechtold, G. L. Borsheim, M. D. Crippen, D. R. Dickinson, G. L. Fox, D. W. Jeppson, M. Kummerer, J. M. McLaren, J. D. McCormack, A. Padilla, B. C. Simpson, and D. D. Stepnewski, 1992, Ferrocyanide Waste Tank Hazard Assessment - Interim Report, WHC-SD-WM-RPT-032, Rev. 1, Westinghouse Hanford Company, Richland, Washington.

Hanlon, B. M., 1993, Tank Farm Surveillance and Waste Status Summary Report for June 1993, WHC-EP-0182-63, Westinghouse Hanford Company, Richland Washington.

McLaren, J. M., 1993, Ferrocyanide Safety Program: Updated Thermal Analysis Model for Ferrocyanide Tanks with Application to Tank 241-BY-104, WHC-EP-0669, Westinghouse Hanford Company, Richland, Washington.

McLaren, J. M., 1994, Ferrocyanide Safety Program: Thermal Analysis of Ferrocyanide Tanks, Group I, WHC-EP-0729, Westinghouse Hanford Company, Richland, Washington.

Poppendiek, H. F., B. Trimailo, G. Boehme, and T. Saka, 1993, Thermal Conductivity Testing \& Specific Heat Testing: Kaiser Engineers' Hanford Project, W236A (Multi-Function Waste Tank Facility), GLM-594, Geoscience, Ltd. Solana Beach, California.

Scaif, C. C. III, 1991, Temperature Measurement Error Analysis, WHC-SD-WM-TI-483, Westinghouse Hanford Company, Richland, Washington. 


\section{WHC-EP-0794}

This page intentionally left blank. 
APPENDIX A

METEOROLOGICAL DATA

A-1 
This page intentionally left blank. 


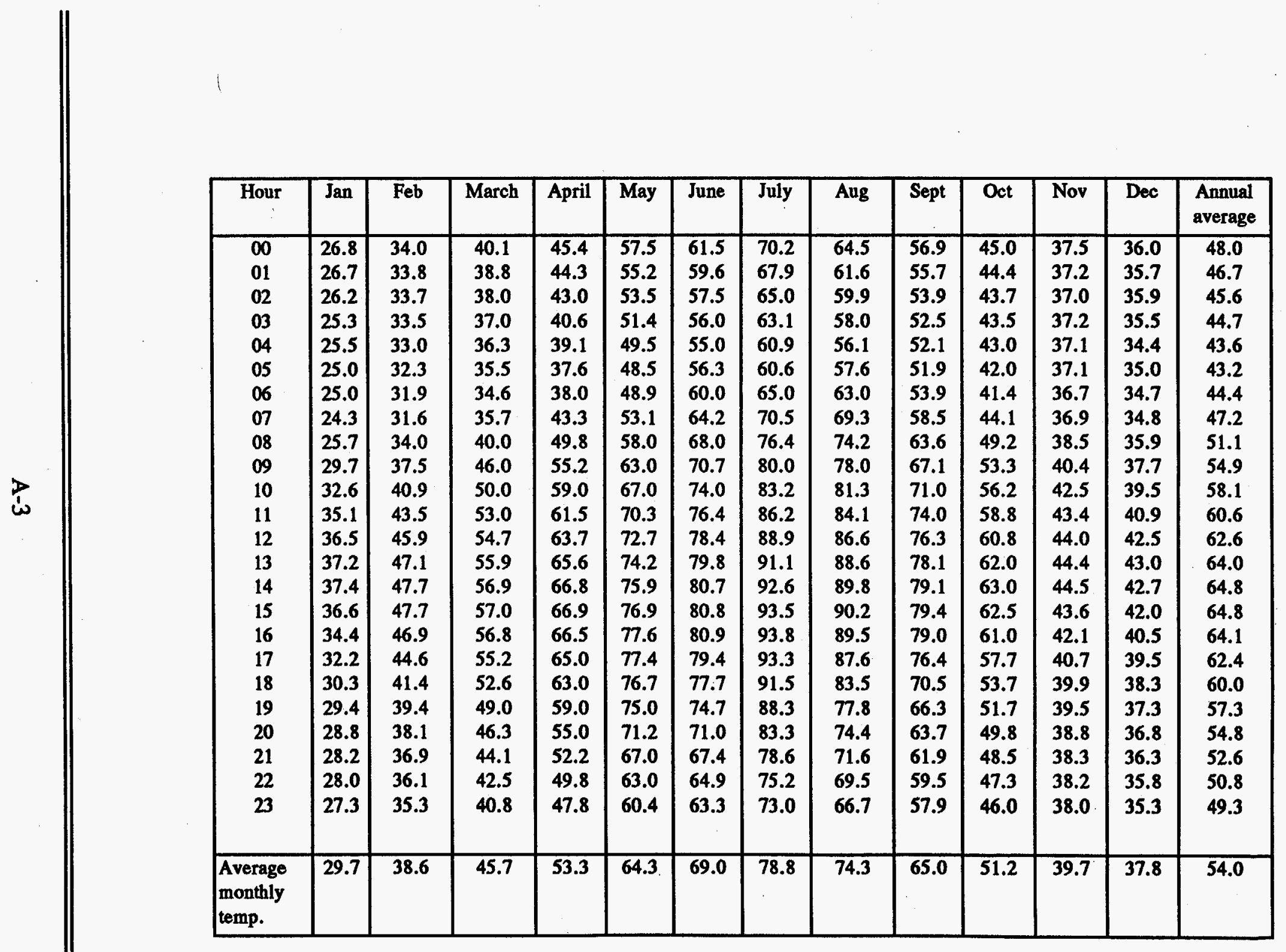




\section{WHC-EP-0794}

Table A-2. Monthly Average of Hanford Site Psychrometric Temperature Data Based on Period of Record from 1950-70 (Temperatures in ${ }^{\circ} \mathrm{F}$ ).

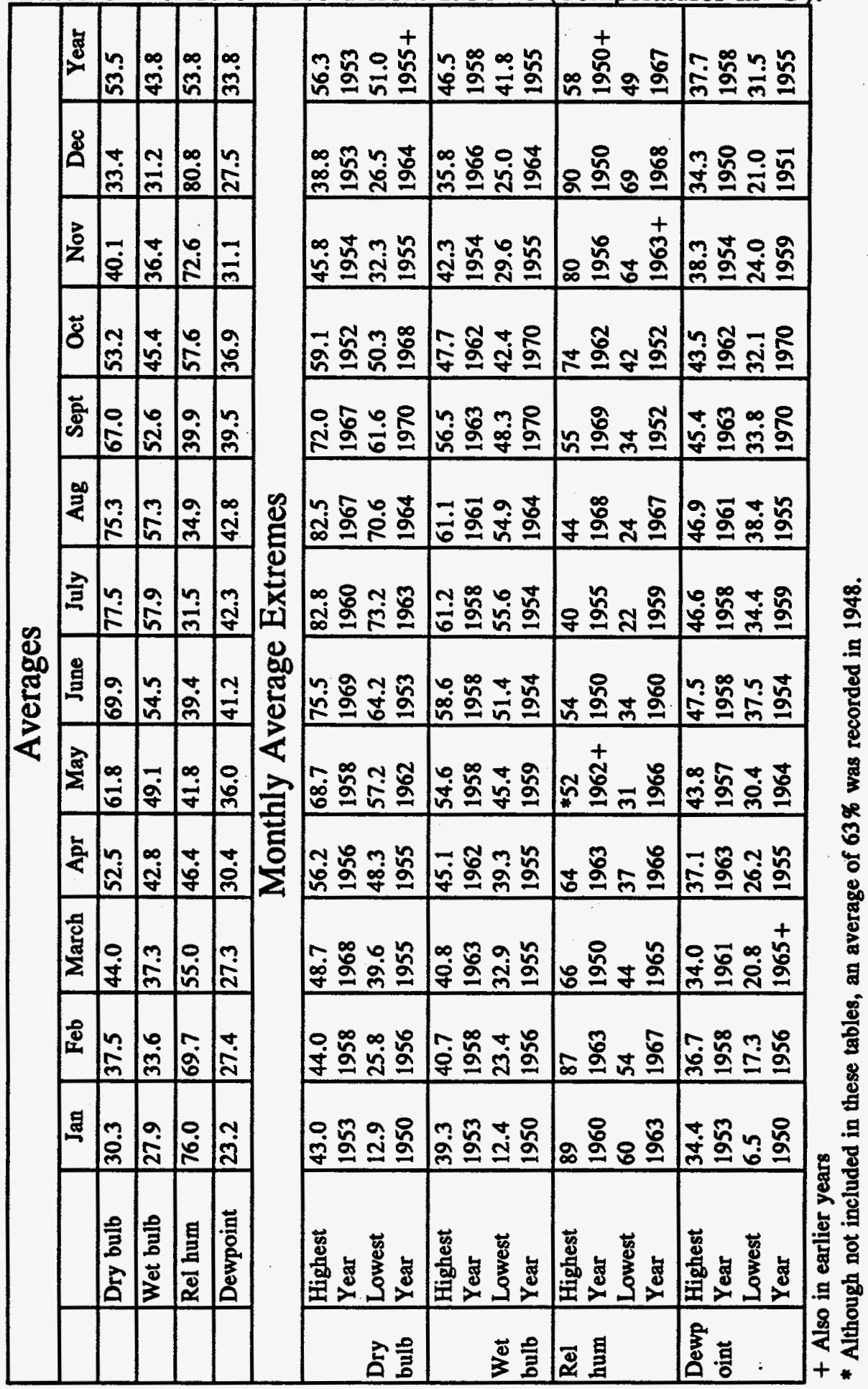




\section{DISTRIBUTION}

Number of copies

\section{OFFSITE}

7

U.S. Department of Energy

EM-36, Trevion II

12800 Middlebrook Road

Germantown, MD 20874

James V. Antizzo

Charles O'Dell (5)

1.

EH-15, Trevion II

12800 Middlebrook Road

Germantown, MD 20874

Shirley Campbell-Grizzel

1

U.S. Department of Energy

Savannah River Operations Office

P.O. Box A

Aiken, South Carolina 29808

Thomas C. Temple

1

Charles S. Abrams

1987 Virginia

Idaho Falls, ID 83404

1

David O. Campbell

102 Windham Road

Oak Ridge, TN 37830

1

Fred N. Carlson

6965 North 5th West

Idaho Falls, ID 83401

1

Billy C. Hudson

2472 Marbury Road

Livermore, CA 94550 


\section{DISTRIBUTION (continued)}

Number of copies

\section{OFFSITE}

1

Arlin K. Postma

3640 Ballard Road

Dallas, Oregon 97338

1

William R. Prindle

1556 Crestline Drive

Santa Barbara, CA 93105

1

Alfred Schneider

5005 Hidden Branches Drive

Dunwoody, GA 30338

1

Air Products \& Chemicals, Inc. 7201 Hamilton Blvd

Allentown, PA 18195-1501

George E. Schmauch

1

Battelle Columbus Laboratories

505 King Avenue

Columbus, OH 43201-2693

James A. Gieseke

1

Brookhaven National Laboratory

Upton, NY 11973

Kamal K. Bandyopadhyay

1 Design Science, Inc.

163 Witherow Road

Sewickley, PA 15143

Gary Powers 
DISTRIBUTION (continued)

Number of copies

\section{OFFSITE}

Fauske and Associates, Inc. 16W070 W. 83rd St.

Burr Ridge, II 60521

Hans K. Fauske

1

Florida State University

Department of Chemistry B-164

Tallahassee, FL 32306

Greg R. Choppin

1

Harvard University

295 Upland Avenue

Newton Highlands, MA 02161

Melvin W. First

1

Hazards Research Corporation

200 Valley Road, Suite 301

Mt. Arlington, NJ 07856

Chester Grelecki

3

Los Alamos National Laboratory

P.O. Box 1663

Los Alamos, NM 87545

Steve F. Agnew

Steve W. Eisenhawer

Thomas E. Larson

1

MIT/Department of Nuclear Engineering

77 Massachusetts Ave.

Room 24-102

Cambridge, MA 02139

Mujid S. Kazimi 
Number of copies

\section{OFFSITE}

Nuclear Consulting Services, Inc.

P.O. Box 29151

Columbus, OH 43229-0151

J. Louis Kovach

Oak Ridge National Laboratory

1

Emory D. Collins

P.O. Box 2008

7930, MS-6385

Oak Ridge, TN 37831-6385

1

Charles W. Forsberg

P.O. Box 2008

MS-6495

Oak Ridge, TN 37831-6495

1

Thomas S. Kress

P.O. Box 2009

9108, MS-8088

Oak Ridge, TN 37831-8088

1

Rice University

5211 Paisley

Houston, TX 77096

Andrew S. Veletsos

2

Sandia National Laboratories

P.O. Box 5800

Albuquerque, NM 87185

Dana A. Powers, MS-0744

Scott E. Slezak, MS-0741 


\section{DISTRIBUTION (continued)}

\section{Number of copies}

\section{OFFSITE}

Germantown, MD 20874

Ray S. Daniels (3)

1

State of Washington

Department of Ecology

P. O. Box 47600

Olympia, WA $98504-7600$

Michael T. Gordon

1

Alex Stone

1315 W. 4th Avenue

Kennewick, WA 99336

1

University of South Carolina

Department of Electrical and Computer Engineering

Swearingen Engineering Center

Columbia, SC 29208

Joseph S. Byrd

1

University of Washington

Center for Process Analytical Chemistry

Chemistry Department BG-10

Seattle, WA 98195

Bruce R. Kowalski

1

Vanderbilt University

P.O. Box 1596, Station B

Nashville, TN 37235

Frank L. Parker 


\section{DISTRIBUTION (continued)}

Number of copies

\section{OFFSITE}

1

Waste Policy Institute

555 Quince Orchard Road, Suite 600

Gaitherburg, MD 20878-1437

Donald T. Oakley

\section{ONSITE}

12

U.S. Department of Energy.

Richland Operations Office

R. F. Christensen (4)

R. E. Gerton (4)

A. G. Krasopoulos

Public Reading Room

$\mathrm{H} 2-53$

RL Docket File (2)

H5-36

9

Pacific Northwest Laboratory

S. A. Bryan

P7-25

A. R. Felmy

K6-82

B. M. Johnson

K1-78

M. A. Lilga

P8-38

B. P. McGrail

K2-38

R. D. Scheele

P7-25

G. F. Schiefelbein

P8-38

D. M. Strachan

K2-44

Hanford Technical Library

P8-55

Westinghouse Hanford Company

H. Babad

T. J. Bander

HO-33

J. B. Billetdeaux

S7-16

D. C. Board

S1-57

G. L. Borsheim

H5-27

S. R. Moreno

B3-06

R. J. Cash (2)

S7-15

M. D. Crippen

L5-31 


\section{DISTRIBUTION (continued)}

Westinghouse Hanford Company (continued)

R. D. Crowe

H4-68

D. R. Dickinson

L5-31

G. T. Dukelow

S7-15

J. M. Grigsby

H4-62

M. E. Huda

R3-08

M. N. Islam

R3-08

D. W. Jeppson

L5-31

N. W. Kirch

R2-11

C. A. Kuhlman

B3-30

M. Kummerer

H4-62

J. M. McLaren (3)

H0-34

J. E. Meacham

S7-15

N. J. Milliken

H4-62

M. A. Payne

S7-14

D. M. Ogden

H0-34

F. R. Reich

L5-63

C. P. Schroeder

L7-06

B. C. Simpson

R2-12

H. Toffer

H0-38

W. T. Watson

HO-38

W. D. Winkelman

L5-55

D. D. Wodrich

S7-84

Central Files

L8-04

Document Processing and Distribution (2)

L8-15

EDMC

H6-08

OSTI (2)

L8-07

TFIC

R1-20 